\title{
Varieties of state capital: What does foreign state-led investment do in a globalized world?
}

Milan Babić ${ }^{1}$, Adam Dixon², Jan Fichtner ${ }^{3}$

\section{Abstract $\quad$ Forthcoming in Competition \& Change}

Existing studies have scrutinized the rise of states as global owners and investors, yet we still lack a good understanding of what state investment does in a globalized economy, especially in host states. Comparative capitalisms research has analyzed foreign state investment as a potential source of patient capital for coordinated and mixed-market economies. However, this patient capital framework cannot explain the recent surge of protectionist sentiments, even among the 'good hosts' of state-led investment. Therefore, we go beyond the patient capital argument and develop a novel framework centered on the globalized nature of foreign state investment. We create and empirically illustrate a novel typology based on different modes of cross-border state investment - from financial to strategic - and different categories of host states. Our results provide a new pathway to study the rise and effects of cross-border state investment in the twenty-first century.

Wordcount: 10.918 (without abstract)

Keywords: varieties of capitalism; internationalization; multinational firms; political economy; state

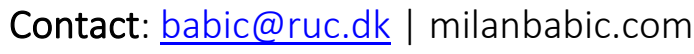

${ }^{1}$ Roskilde University

Department of Social Sciences and Business

Universitetsvej 1 | 4000 Roskilde | Denmark

${ }^{2}$ Maastricht University - SWFsEUROPE | swfseurope.com Faculty of Arts and Social Sciences (FASOS)

Grote Gracht 90-92 | 6211 SZ Maastricht | The Netherlands

${ }^{3}$ University of Amsterdam - CORPNET | corpnet.uva.nl

Department of Political Science

Nieuwe Achtergracht 166 | 1018 WV Amsterdam | The Netherlands 


\section{Introduction}

Over the last decade, foreign state investment ${ }^{1}$ has moved from being a relatively new phenomenon in the global economy to the center of disputes about foreign investment screening mechanisms, rising protectionism, and renewed global rivalries. When states rose as global owners and investors in the 2000s, the comparative capitalisms (CC) literature treated this type of investment usually as new, but often welcome opportunity for coordinated and mixed-market economies (CMEs and MMEs) ${ }^{2}$ to overcome various problems related to the provision of patient capital (Deeg \& Hardie, 2016; Kaplan, 2016; Thatcher \& Vlandas, 2016). ${ }^{3}$ From this patient-capital angle, globalization and financial liberalization, which were initially perceived as a potential threat to the stability of 'insider' corporate governance systems of CMEs and MMEs (Culpepper, 2005), would be embraced in many cases by industrial and policymaking coalitions interested in preserving patient capital-dependent growth models (Thatcher \& Vlandas, 2016). After the 2008 global financial crisis (GFC), some state-owned vehicles such as sovereign wealth funds (SWFs) were on the way to become the saviors of global finance, injecting desperately needed capital in Western banks (Helleiner \& Lundblad, 2008), and even protecting German industrial capital from foreign takeovers (Haberly, 2014).

Recently, however, we have seen opposite trends manifesting across capitalist varieties. Measures such as the introduction of EU-level foreign direct investment (FDI) screening mechanisms in 2018 (De Jong \& Zwartkruis, 2020), or the tightening of US regulations under the Foreign Investment Risk Review Modernization Act (FIRRMA) of 2018 (Zimmerman, 2019), have significantly curtailed the possibility of, among other, large-scale

\footnotetext{
${ }^{1}$ In this paper, we understand 'transnational state capital' and 'foreign state investment' as describing the same phenomenon from different perspectives: the first describes state-owned (economic) capital in the form of equity, bond, or cash ownership; while the latter describes the process of cross-border investment of this capital.

${ }^{2}$ We treat CMEs and MMEs in this paper as being similarly affected regarding the patient capital argument: both varieties differ from liberal market economies in the sense that they rely on non-market coordination mechanisms, of which patient capital is one form. CMEs rely more on functioning networks of firms, banks, trade unions and other social forces, whereas MMEs are more reliant on the state as mediator of societal interests and as target of lobbying (see Hassel, 2014, pp. 5-10).

${ }^{3}$ Outcomes in CMEs and MMEs are typically considered to be less driven by direct market pressures, but mediated by the embeddedness of firms in networks and relationships that facilitate non-market coordination (Hall and Sokice, 2001, 8). ,Patient' capital plays a key role here because it provides financing beyond quarterly profit expectations. It enables firms to engage in longer-term planning and hence contributes to the establishment of networks and relationships between firms and banks (or other finance providers) typical for CMES and some MMEs (see also Braun and Deeg, 2020).
} 
state investment into nominally open economies. Even formerly 'patient capital' focused economies like Germany or France have become increasingly more hostile toward some state investors, instituting corresponding protectionist measures (Stompfe, 2020). Concomitantly, some forms of state investment, such as long-established ties of Gulf States sovereign wealth funds in the German car industry, are still a welcome source of funding (Haberly, 2014). In fact, the Covid-19 crisis even expanded the diversification and asset acquisition attempts from some state-owned actors, yet without stirring up major controversies. ${ }^{4}$ This exemplifies that foreign state investment is not reducible to one specific form alone but displays a polymorphic character (XXXX \& AUTHOR 2, XXXX).

We argue that in order to understand this polymorphism and its variegated effects on host states, we need to go beyond the CC-focus on specific investment vehicles and particular national capitalist varieties and take into account the globalized nature of foreign state investment. We do so in three steps: first, we expand the temporal focus of the analysis beyond the GFC and its immediate aftermath. This allows us to incorporate the rise of state capital over the last decade, in which state capital established itself as a transnational force (Haberly \& Wójcik, 2017). Second, we broaden the focus on state capital beyond specific vehicles or functions (such as SWFs or patient capital) and include all types of foreign state investment in our analysis. This helps us to gain a better understanding of the phenomenon as a whole, instead of specific investment vehicles. Third, we extend the analytical scope of the targets of state investment beyond CMEs or MMEs, which are typically studied as receivers of patient capital (Deeg et al., 2016). The rise of state capital as a global force necessitates a global focus incorporating all capitalist varieties and how they deal with this rise. Taken together, our study explores for the first time the changing nature of foreign state investment and its effects on host states in a comprehensive manner.

The paper contributes theoretically to a newly emerging research program on the 'new' state capitalism (XXXX and AUTHOR 2, XXXX; XXXX et al., XXXX). Different from 'classical' CC research, the new state capitalism perspective takes the globalized nature of state capital

\footnotetext{
${ }^{4}$ This was, e.g., done by SWFs like Saudi Arabia's PIF, which diversified its portfolio due to Covid, buying stakes in hotel chains, event management firms, or cruise operators (England \& Massoudi, 2020). Similarly, Norway's sovereign fund expanded its stakes in US firms like Shell (Weiss and Holter 2020). But also other state-owned entities expanded their grip at home and abroad for various reasons such as support for Covid-affected industries to global expansion ambitions (see OECD 2020; UNCTAD 2020, 34).
} 
seriously (AUTHOR 1, XXXX). Recent research has demonstrated how state capital established itself within transnational ownership and investment networks, enabled and promoted by neoliberal globalization (AUTHOR 1 et al., XXXX2; Haberly \& Wójcik, 2017). Our contribution to this literature is a typology which incorporates the three aspects described above and for the first time integrates the sender- and host-side of transnational state capital into a comprehensive analytical framework. We hold that such a typology can help to better guide empirical research into the effects and political reverberations of the rise of state capital. The paper proceeds by outlining the CC-reasoning on the relationship between financial liberalization and the provision of patient capital through foreign state investment (section 2). It then provides an alternative explanatory framework that takes the globalized nature of foreign state investment seriously (section 3). Thereafter, we illustrate our introduced typology with four empirical vignettes (section 4). We close by discussing and embedding our findings in a broader research agenda on state capital in a changing global environment (section 5).

\section{Financial liberalization and the relative patience of foreign state} investment

\section{The demise of traditional patient capital and the rise of state capital}

Globalization and the concomitant financial liberalization from the late 1980s onwards both enabled and challenged research interested in comparing capitalist varieties. The field gave a rationale for better understanding the diversity of national economic models notwithstanding global convergence pressures (Albert, 1993; Amable, 2003; Hall \& Soskice, 2001). Yet, many observers emphasized that these very pressures would, in their estimation, eventually destabilize, internally diversify, or even obliviate existing varieties in the long run (AUHTOR 2, XXXX; AUTHOR 3, XXXX; Gilson, 2001). Both argumentations build on the idea that globalization exposed different types of formerly 'closed' corporate governance systems to global markets. These market dynamics were not affecting each corporate governance type identically. Naturally, market-coordinated 'outsider' systems such as liberal market economies (LMEs) are better suited to deal with impatient investors who are focused rather on short-term profitability than long-term relationships with their invested firms (Hall \& Soskice, 2001, 16). Network-based coordination systems of the type we find in CMEs and MMEs are, however, built on long-lasting 'insider' relationships between corporations and investors, which are 
potentially endangered by globalization. The entrance of investors seeking short-term returns on investment led to a competition with more traditional sources of corporate funding and in some instances replaced them (AUTHOR 3, XXXX). Other institutional complementarities in CMEs and MMEs were also affected by these dynamics, such as labor relations and social policy (Mills et al., 2008). Consequently, during the late 1990s and early 2000s, globalization and financial liberalization were increasingly perceived as problematic for the stability of the nonmarket-based coordination systems of CMEs and MMEs.

A key instrument on behalf of those systems in dealing with these dynamics is patient capital (Hall \& Soskice, 2001). This type of finance, which is 'not entirely dependent on publicly available data or current returns' (ibid., 22), enables firms in CMEs and MMEs to withstand the impatient forces of 'quarterly capitalism' and to create more incremental long-term innovation. Consisting of equity and debt supplied by actors embedded in (mainly national) networks of corporate governance, patient capital is built on trust and long-term investment by actors such as domestic banks, institutional investors, or families and foundations (Deeg \& Hardie, 2016). The state is another important, but often overlooked provider of patient capital (Haberly \& Wójcik, 2017; Mazzucato, 2015). While the purported function of patient capital in the long run is to create steady innovation and growth, it does so mainly via its ability to shield a company's internal resources from being subjected to and 'burned' by impatient actors seeking short-term gains and even hostile takeovers (Haberly, 2014, 296). Patient capital engages thus not only in the provision of funds, but also in the backing of tight-knit networks with high levels of internal trust in the domestic market for corporate control.

As some observers have noted, the function of patient capital and the role of those domestic networks for CMEs and MMEs has been seriously impaired through developments such as the increased dependence on export-led growth (Braun \& Deeg, 2020), the decrease of blockholdings and entrance of impatient investors (AUTHOR 3, XXXX), or structural changes in global capital markets creating further convergence pressures (Lane, 2003). Consequently, internal diversification and institutional change within those economies have weakened the once tight-knit domestic networks of patient capital provision. Since the mid-2000s, the relevant debates hence shifted towards the future and alternative pathways of these insider constellations under pressure (Culpepper, 2005).

One element of these debates is the rise of foreign state investment as a new source of patient capital (Bolton et al., 2011). SWFs grew significantly in the 2000s (XXX et al., XXXX), 
with some becoming major actors in global finance during and after the GFC. As foreign stateowned investment vehicles, SWFs were initially eyed with suspicion regarding their political allegiances to their home states. However, this skepticism gave way to an embrace of the important role SWFs played in stabilizing ailing Western financial institutions during the GFC (Helleiner \& Lundblad, 2008). Soon, policy-makers in developed economies discovered SWF investment as an attractive source of patient capital. French and German coalitions between policy-makers and large industrial firms proactively sought to attract SWF investment into their domestic economies (see Thatcher \& Vlandas, 2016). These outside state investors are deemed especially attractive for insider (CME and MME) systems due to 'their ability to defend internal resources from external demands for short-term 'shareholder value" (ibid., 296) and because SWFs are backed by deep and 'patient' state pockets and have no real liabilities (Monk, 2009). This increases their immunity to short- to medium-term volatility and their investment commitment over the long run. Authors like Kaplan (2016), Deeg and Hardie (2016), Haberly (2014), Thatcher and Vlandas (2016) or Haberly \& Wójcik (2017) have reiterated this argument in different versions.

\section{Limitations of the patient capital-argument}

Summing up the argument so far, foreign state investment is perceived as a serious alternative to the diminishing supply of patient capital in CMEs and MMEs. Yet, we hold that this argument in the literature is built on a relatively limited basis: patient capital usually pertains to a certain type of foreign state capital (SWF or public bank investment). The argument is connected to a specific spectrum of capitalist variety (the coordinated/mixed one). And the time-frame taken into account is short (mainly post-GFC). We argue that through this limited basis, foreign state investment has been narrowly conceived, and mainly theorized as a source of patient capital.

The first aspect concerns the focus on SWFs as providers of patient capital. The apparently seamless integration of SWFs into global financial markets dampened expectations about possible geopolitical backlashes emanating from state-led investment. At the same time, corporate takeovers and other problematic large-scale investments from state-owned vehicles were on the rise. One major example was the controversy that erupted in 2006 around stateowned Dubai Ports World's purchase of UK-based ports operator P\&O. The latter had contracts to operate major US ports, but due to domestic political pressure the new owner relinquished 
them (Rose, 2008). The growth of cross-border activity of major state-owned oil companies also became controversial. For example, Chinese oil company CNOOC's unsolicited bid for USbased Unocal in 2005 was taken up as an issue in the US Congress, eventually leading CNOOC to withdraw its offer. Within the EU, it was especially Chinese (state) investment that rapidly grew after the GFC and stirred up debates about new, also protectionist, ways of dealing with this influx. Today, transnational state-owned enterprises (SOEs) are a major point of security and political concerns within host states (Cuervo-Cazurra, 2018).

This rise of non-SWF and non-portfolio investment does not integrate well with the patient capital argument. One of the key reasons for why state investment might be an adequate alternative source of patient capital is its alleged ability to prevent hostile takeovers (Haberly, 2014, 296; Thatcher \& Vlandas, 2016, 650; see also Hall \& Soskice, 2001, 40). This function ceases to be relevant if the overseas state investor is itself the instigator of this takeover as described above. Overall, extending the focus of foreign state investment beyond SWFs poses a key challenge to the patient capital-framework.

The second aspect concerns the timeframe of the analysis, which is often limited to the phase around the GFC. From today's perspective, this focus concerns a limited period, in which SWFs were the primary state-owned vehicles that engaged in cross-border investment. As our analysis in the next section shows (Fig. 1), both the level as well as the polymorphism of stateowned vehicles investing abroad increased in the decade that followed the GFC. State-owned vehicles with different aims and working logics were quickly gaining global attention. This rise of more politically sensitive forms of foreign state investment continued until today, for example through large-scale Russian investments in India (The Asian Age, 2017), Malaysian state-led takeovers of Canadian oil firms (Henderson, 2013), and failed Chinese bids for critical European infrastructures (Wise, 2019). Such examples dominate current discussions about foreign state investment and its security implications. The limited focus on the post-GFC state investment landscape does not consider the largest chunk of post-crisis investment flows, which are predominantly large-scale takeovers and other types of SOE-led investment. Currently, most of foreign state investment (close to 60 percent) is located in majority stateowned corporations (AUTHOR 1 et al., XXXX2, PAGE). Additionally, many SWFs themselves proved to not necessarily embrace a clear-cut patient capital orientation, but rather pursued portfolio investment strategies typical of other large diversified institutional investors. Importantly, these also include 'impatient' investments, shaped by short-termism and quick 
exits in cases of poor performance (Deeg \& Hardie, 2016, 640). The fact that they can engage in some instances in long-term provision of financial resources excludes the many other asset allocation strategies SWFs engage in (XXXX et al., XXXX). A broadened timeframe is hence analytically useful to determine the overall effects of foreign state investment.

The third aspect concerns the fact that the focus of analysis of foreign state investment in CC research are CMEs and MMEs like Germany or France (Thatcher \& Vlandas, 2016). While this makes theoretical sense, this focus overestimates the conduciveness of $\mathrm{CME} / \mathrm{MME}$ institutions to transnational state capital. It also underestimates the attractiveness of LMEs and other capitalist varieties for foreign state investment. The first aspect relates to the fact that patient capital depends on the tight domestic networks that provide 'insider' information relevant for the investor to determine the viability of (long-term) investment (Hall \& Soskice, $2001,22)$. This aspect is almost absent in relation to overseas state outsiders, which have no means to adequately replace those tight-knit network relations built over decades. A strong emphasis on the institutional complementarities of CMEs/MMEs and overseas, 'patient' stateowned capital overestimates the ability of foreign state investment to seamlessly integrate into existing networks. In fact, CMEs and MMEs with strong corporate networks are even more likely to display political resistance against foreign investment threatening those networks (Callaghan, 2015). The second aspect relates to the strong presence of state investment among other types of capitalist varieties, namely LMEs. The United Kingdom, Australia, and the United States are among the top global targets for different forms of transnational state capital (AUTHOR 1 et al., XXXX2). Here, arguments about the function of foreign state investment as patient capital are not applicable, but require different explanatory frameworks.

Taking state capital as diverse and 'polymorphic' (XXXX \& AUTHOR 2, XXXX), the patient capital framework focusing on particular vehicles, particular host states, and a particular time frame is too narrow to explain this polymorphism. Building on this critique, we develop a broader framework that takes as central the globalized nature of foreign state investment, which allows us to study its major effects on different political economies over time.

\section{Beyond patient capital: foreign state investment in a globalized economy}

To go beyond the limitations of the patient capital-framework, we propose to take the transnational nature of foreign state investment seriously. Recent research has demonstrated how state capital integrated successfully into global corporate and investment networks over 
the last two decades (AUTHOR 1 et al., XXXX2; Haberly \& Wójcik, 2017). State capital thereby competes with 'private' capital for returns on investment across different asset classes. Simultaneously, state capital re-articulates state power to a certain extent in the global political economy (AUTHOR 1, XXXX). It permits 'small' states to extend their geopolitical reach (Braunstein, 2018), creates opportunities for technology transfer for larger powers (Hannas \& Tatlow, 2020), enables some states to benefit from financial globalization (XXXX et al., XXXX), or offers possibilities for other states to increase their relative political power in the international system (Lenihan, 2014). The rise of states as global owners and investors amplified their abilities to wield (political) power in the global economy. We incorporate this polymorphism of transnational state capital in Table 1.

\begin{tabular}{|c|c|c|}
\hline Perspective & Patient capital & Transnational state capital \\
\hline Investment vehicles & Mainly SWFs & $\begin{array}{c}\text { All types of foreign state } \\
\text { investment }\end{array}$ \\
\hline Time span of the analysis & During/around the GFC & Since the GFC \\
\hline Investment targets & CMEs and MMEs & All types of capitalist \\
& & varieties \\
\hline
\end{tabular}

Table 1: Comparison of patient capital and transnational state capital perspectives.

To summarize our framework, we first include all types of foreign state investment instead of focusing on one particular type of investment vehicle. Recent studies have argued for the inclusion of different types of state investment for the explanation of political phenomena (Carney, 2018) and the transnational integration of state capital (Haberly \& Wójcik, 2017). Such a comprehensive approach is also backed by political realities: many states which, for example, tightened foreign investment screening mechanisms in recent years did not target specific vehicles. Rather, it is the concrete amount of acquired corporate control and the strategic nature of the investment that are relevant variables for the assessment of foreign (state) investment by screening agencies. This speaks to the need to better understand the overall effects of foreign state investment beyond reducing it to a specific form. 
Second, we extend the time span of the analysis beyond a focus on the post-GFC period. Evidence from cross-border mergers \& acquisitions (M\&As) indicates that the peak of stateled projects was indeed around the GFC, where the state share of global M\&As amounted to over a fifth of all deals (Fig. 1 (A)). However, the yearly average global share doubled from about 5\% to $10.7 \%$ after the GFC (Fig.1 (B)), which points to a growth of the presence of state capital in the global economy.

(A)
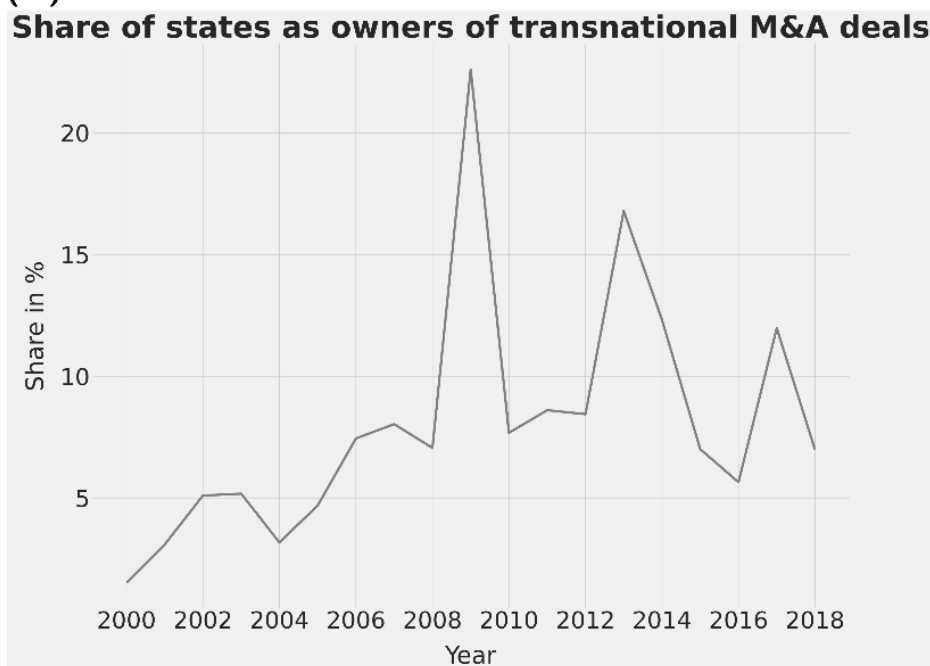

(B)

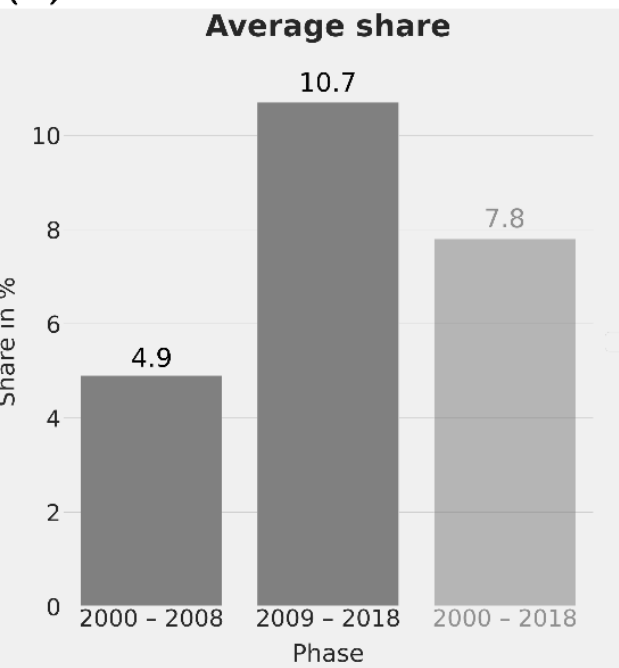

Figure 1: Share of states as owners of all transnational M\&A-deals from 2000-2018 (A) and average share over different phases (B). Source: own calculations based on Bureau van Dijk's Zephyr database.

Besides M\&As, other indicators also point to a steady growth of the presence of state capital in the global economy in the last decades. SOEs, for example, increased their share in the Fortune Global 500 list from below 10\% in 2005 to almost a quarter of all firms in 2014 (Kwiatowski and Augustynowicz, 2015). This tendency is also clear for SWFs that held less than USD 1tn in assets under management (AuM) in 2000. This amount grew to just below USD 4tn when the Global Financial Crisis hit in 2008 and then more than doubled in the last decade to reach the USD 9tn threshold in 2020 (Norrestad, 2021a). The growth of SWF presence in the global economy has almost been linear in these two decades. Compared to other large, 'private' institutional investors, SWFs are big players: they approximately control around 10\% of the USD 100tn global AuM currently managed (Heredia et al., 2021) and they are double as big as hedge funds that held below USD 4tn in AuM in 2020 (Norrestad, 2021b). Together with 
the recent politicization of state investment described above, we hence hold that a broader timeframe is necessary to understand the variegated nature of foreign state investment.

Thirdly, we expand the universe of hosts of state capital beyond MMEs and CMEs. As mentioned, non-MME or CME economies are also key targets for foreign state investment and experienced respective disputes in recent years. Including further capitalist varieties in the analysis also allows to test claims about foreign state investment on a broader and comparative basis. We contend that extending the scope of the analysis potentially reveals patterns of domestic policy reactions that are similar across different capitalist varieties and thus point to the need to sharpen and expand explanatory frameworks.

Based on these considerations, we now move to develop a typology of foreign state investment based on the distinction between senders and hosts of this investment.

\section{Towards a typology of foreign state investment}

\section{State investment strategies in the global political economy}

The first aspect of our typology concerns the sender-side of state investment. Since we are interested in the effects of foreign state investment in the global economy, we consider only cross-border investment. State capital that does not cross borders is unlikely to directly affect other states or actors in the global economy.

To facilitate a more nuanced understanding of foreign investment in a changing global political economy, we develop a novel typology of the different 'roles' that state-owned capital plays in different (national) contexts. We argue that transnational state capital can be mapped onto a continuum that has two poles: on the one end there is state capital which first and foremost seeks a return on investment and thus pursues a diversified portfolio strategy akin to private investors. This type of state capital is arguably less distinguishable from 'normal', private portfolio investment. At the other end of this continuum are state-owned investors which are primarily driven by geoeconomic and even geopolitical motives and thus interested in issues beyond the maximization of financial returns. Such motives could be the acquisition of valuable assets, technological know-how, or competitors in global industries. In extreme but rare cases, state investment is even used for reaching geopolitical goals. This form of state capital seeks to influence its foreign investment targets for political reasons. Other kinds of state-directed capital fall in between these two forms. Instead of a dichotomy between patient 
and impatient (foreign) capital we hence propose a spectrum that ranges from financially motivated to strategically driven forms of transnational state capital (Figure 2):

Financial Investment $\mid$ Strategic Investment

Figure 2: Spectrum of cross-border state capital from financial to strategic investment.

In principle, this spectrum could be mapped onto the continuum from portfolio investment (small ownership stakes of less than 10 percent) to majority investment (large ownership stakes greater than 50.01 percent), as AUTHOR 1 et al. (XXXX2) do. In our conceptualization, however, we do not want to exclude state investment that does not end up as equity ownership, but incorporate all types of state capital that crosses borders. While most of this investment consists of equity investment, we also know of other forms of cross-border state capital such as bond investment, bank credits, and loans (Lee, 2017). Those forms usually do not realize a direct ownership stake in a company. Our typology also captures such forms of state investment and places them on the spectrum from financial to strategic investment.

It is important to understand that we do not claim that each form of state capital is 'fixed' on this continuum. Lending for example can sometimes be more or less strategic, and the same holds for other forms. Here, we want to describe the average or 'normal' case for each of those forms: lending will usually not tend to be highly strategic or even geopolitical. The same applies to asset-capture: such investment will usually not go unnoticed and be qualified rather as a strategic means of state capital internationalization. The positions of each form on this continuum are hence rather aggregate than fixed positions; and particular cases can deviate from this aggregate position.

In addition, we emphasize that Fig. 2 does not make strong assumptions about the respective motivations of each investment conducted by state-owned vehicles. This is per se difficult to capture and quantify analytically (see AUTHOR 1, XXXX). Rather, we qualify investment types by what they typically do (e.g. capture assets or return a profit). This allows us to connect the agency of the investing vehicle with the reaction by the host state (see next section) without necessarily claiming to uncover the 'true motives' of each investment decision. 
The presented typology has one key advantage over typologies that instead rely on investment vehicles: we do not preclude that specific vehicles like pension funds or SWFs invest in one specific way, but take the polymorphism of state-led investment seriously. As an example, we know that different SWFs invest in a variety of forms and types, from pure portfolio investment, to financing real estate development abroad, to facilitating asset and know-how capture - often within the same SWF (see XXXX et al. XXXX). Our typology reflects this fact by focusing on the investment forms themselves and not the institutions conducting them. In the following, we do not discuss all existing forms of state investment. Rather, we focus on the more prevalent investment types to illustrate our approach.

We start from the left side of Fig. 2. The first type of investment that comes closest to an ideal-typical financial strategy is portfolio investment. We define portfolio investment as investment that does not amount to significant corporate control. ${ }^{5}$ This is for example the case for typical stock market investment that seeks a maximum return on its invested capital. Portfolio investment can be described as financial because return on investment is its principal raison d'être. This is also the case for state capital, as one of the largest sovereign investment classes is investment by SWFs. SWFs often 'mimic' their private peers in terms of (portfolio) investment and diversification strategies (XXXX et al., XXXX). While the motivations for engaging in cross-border portfolio investment differ from SWF to SWF, the realization of this investment can take place only in a limited number of forms. The Norwegian SWF is a prime example for such a portfolio strategy. It is invested in over 9,100 companies in 73 countries and holds assets worth USD 1,370bn under management. In addition, the SWF also owns bonds, real estate and infrastructure assets (NBIM, 2021). Due to its extremely diversified portfolio consisting of thousands of small ownership stakes, the fund has been likened to a giant index fund that replicates the world's stock markets, similar to the giant passive funds that BlackRock is managing ( $A U T H O R 3 \& X X X X, X X X X$ ). The absence of any majority holdings in foreign firms is a clear indicator that the Norwegian SWF does not intend to exert major influence abroad. It does push for sustainability and good corporate governance, but this is not unusual for any large asset manager nowadays and does not indicate strategic motives.

\footnotetext{
${ }^{5}$ This excludes not only majority ownership of a company, but in fact all larger shareholdings like blockholding or 'golden shares', up to an investor becoming the largest shareholder in a company with a small stake in the firm (which can happen in instances of dispersed ownership).
} 
A second type of state capital which is closer to the financial pole is cross-border lending and financing. SWFs are not the only way to recycle excess capital that many commodityexporting states and countries with large trade surpluses have amassed over time. They also engage in cross-border lending and financing through state-owned banks. National development and policy banks have grown significantly in recent years, both in terms of their loan portfolios and financial capabilities, and control assets worth USD 49tn (Marois, 2021, 1). While many have a national focus, there are those, such as the China Development Bank (CDB), that provide significant cross-border financing. Lending abroad is in some respects more strategic than pure portfolio investment. Cases like the CDB, which is involved in substantial contributions to Belt and Road infrastructure projects, demonstrate how cross-border lending and finance can support geostrategic ambitions of powerful states. At the same time, the same CBD is also one of the main protagonists of a 'patient capital' approach of Chinese cross-border lending in Latin America and elsewhere (Kaplan, 2016). Another key form of indirect crossborder lending is the state-led buying of sovereign bonds of other states. States such as China, but also Japan, Norway, and others engage in this type of lending through different stateowned vehicles like Central Banks or SWFs (Arslanalp and Tsuda, 2014). Bond holdings are usually understood as a hedging investment form with little strategic intent. However, global imbalances like the large Chinese holdings of US sovereign debt might in some cases be interpreted or utilized as strategic leverage. Cross-border lending and financing is hence a hybrid form of state capital that combines a return-on-investment logic with the possibility for states to instrumentalize financial institutions for strategic objectives.

Our third type of state capital are so-called national champions. These are partly or majority state-owned firms which were formed in nationally important industries in the 20th century. 'Classical' national champions are European firms from sectors such as utilities or aerospace. During the privatization waves of the 1980s and 90s, many former national champions either reduced their state ownership ${ }^{6}$, or were fully privatized. Some of the companies that remained firmly in majority state ownership became 'international' champions in the 2000s (Viallet-Thévenin, 2015), expanding globally through the build-up of subsidiaries or acquisitions. One major example is the German state-owned Deutsche Bahn and its logistics subsidiary DB Schenker, which have expanded internationally in the last 15 years. Schenker

\footnotetext{
${ }^{6}$ Sometimes below $50 \%$, but in some cases states retained a so-called 'golden share' allowing them to remain the most influential shareholder; e.g. this is the case for the French utility ENGIE.
} 
was able to enter European logistic markets and establish itself as a major player, thereby bolstering the international ambitions of its parent company (Berlich et al., 2017). Similarly, French energy giant EDF expanded internationally and acquired leading nuclear and renewables firms in Europe and the US (EDF, 2016). Such internationalization of former national champions is not per se a geopolitical move, as the economic competition for market shares and sectoral leadership are the prevailing motives (AUTHOR 1, XXXX). However, the strategic nature of this expansion is clearly visible in the reverberations that firms like EDF can cause in their host countries such as in the British nuclear sector (Crooks, 2008).

Even more strategic than (inter)national champions is the state-led capture of assets and know-how, which serves to propel domestic development; or to increase the competitiveness of whole domestic industries. The most prominent case of this strategic outlook is China and its state-owned vehicles engaging in asset- and know-how capture abroad. Chinese state-led acquisitions have increased in size and frequency in the last decade with the 'Made in China 2025' (MiC 2025) industrial strategy. The strategic nature of such asset- and know-how capture is reflected in the fact that many acquired firms such as world-leading small and medium-sized enterprises (SMEs) in countries like Germany fit into the ten key sectors as laid out in the MiC 2025 strategy (Jungbluth, 2018). The largest Chinese state-led acquisition ever - the USD 40bn takeover of Swiss agrochemical giant Syngenta in 2017 - took place amidst a competition for know-how in an ever more consolidated global seed and biotechnology market (Deconinck, 2019). These forms of foreign state investment go beyond issues of direct technology transfer, but involve a range of strategies of asset- and know-how-capture (Hannas \& Tatlow, 2020).

The last investment type of our spectrum is geopolitical investment. By this we decisively do not mean investment that has 'only' geopolitical implications. Such implications have been analyzed even for portfolio investment from SWFs (Braunstein, 2018). Rather, we employ here the classical notion of geopolitics as the projection of state power abroad - in our case via state-owned means. In other words, the weaponization of state ownership to reach political goals is what we understand as a geopolitical investment strategy. To be clear, one is unlikely to find pure geopolitical cases of foreign state investment, since the realization of such strategies always depends on corporate decision-makers, which are one among many players shaping state-corporate power relations (AUTHOR 1 et al., XXXX1). Instead, we will most often find instances where a (partial) amalgamation of state power and corporate interests plays a 
role. A case in point is the relation between the Russian state and its state-owned energy producers, which have been described as a 'foreign policy tool' (Newnham, 2011). In another perspective, powerful firms like Gazprom are driving much of the geopolitical confrontations between Russia and other European states (Abdelal, 2013). Recent cases like the cancelled Nord Stream 2 project, which has a clear geopolitical edge disuniting EU member states, are fundamentally carried out by state-owned giants like Gazprom. This mutual dependency between corporate power and state interest is a clear-cut case of geopolitical competition through state-owned means.

\section{Host state reactions to state capital}

In the description of different foreign state investment strategies, we already touched upon the possible reverberations state capital can induce in host states. In order to move beyond the discussed complementarities between CMEs/MMEs and particular forms of state capital, we introduce a second dimension to our typology that represents the host state side of foreign state investment, namely a continuum from high-to low-income economies. This choice goes beyond the CC-typologies, but takes all types of capitalist varieties into account as possible investment hosts.

By mapping the host states along this axis, we assume that each invested unit has, ceteris paribus, a larger effect on national income the lower this national income of an economy is. This means that for governments of low- or middle-income economies, all forms of state investment can also be an attractive source of funding. Such investment can, for example, be used to gain more fiscal and policy space as has been argued for Latin America (Kaplan, 2016). Similarly, Chinese state capital in African countries presents potential for development, while the effects on the ground, for labor, environmental, and social relations are often problematic (Lee, 2017). Recent large-scale Russian state investment in India has also been pushed through at the highest levels of the Indian government, against political and economic concerns (Zhdannikov et al., 2016). On the other side of this spectrum, high-income economies can be more selective about incoming FDI flows, especially if they emerge from statist competitors like China or Russia. Discussions around the recent tightening of investment screening mechanisms in the UK (Browning \& Bennett, 2021), the EU (Stompfe, 2020), or the US (Zimmerman, 2019) explicitly reference state investment and the associated national security threats as a key motivation. In weighting investment attraction interests and possible 
national security infringements - for example through asset, know-how, or infrastructure takeover - we argue that higher-income economies have more policy space to reject and block state investment. In addition, higher-income economies are also more likely to host worldleading industry firms which could become targets of state-backed acquisition attempts. This makes the likelihood of unwanted takeover bids for valuable corporate assets and know-how more likely than in low- or middle-income countries.

Yet, such rejection and political backlash in high-income economies decreases when foreign state investment moves closer to the financial side. Besides clearly non-controversial forms like portfolio investment, long-standing financial ties such as between Gulf States SWFs and European industry firms also fall within this category. While there have been some reservations in the past towards state-owned funds in countries like Germany (Heep, 2008), the overall sentiments are rather neutral to positive. The different political implications of financial and strategic investment for high-income countries can also be seen in the political backlash in the US against the Dubai Ports World takeover of ports operator P\&O in 2006 described in section 2, despite large and regular flows of portfolio investment from Gulf States SWFs into US stock markets. In other words, non-strategic state-led financial inflows should in principle not be a major political problem for either high or middle/low-income economies (see also AUTHOR 1, XXXX) - although the dependence of the latter group of countries on these investment inflows and its ensuing unequal power relations is an important structural factor.

We integrate these dynamics by mapping both of our dimensions together (Figure 3). Our basic argument is that by distinguishing, ceteris paribus, between financial and strategic investment on the side of the sender, and high- and middle/low-income economies on the side of the investment host, we can map the landscape of foreign state investment and its possible consequences in the global economy. 
High-income economies

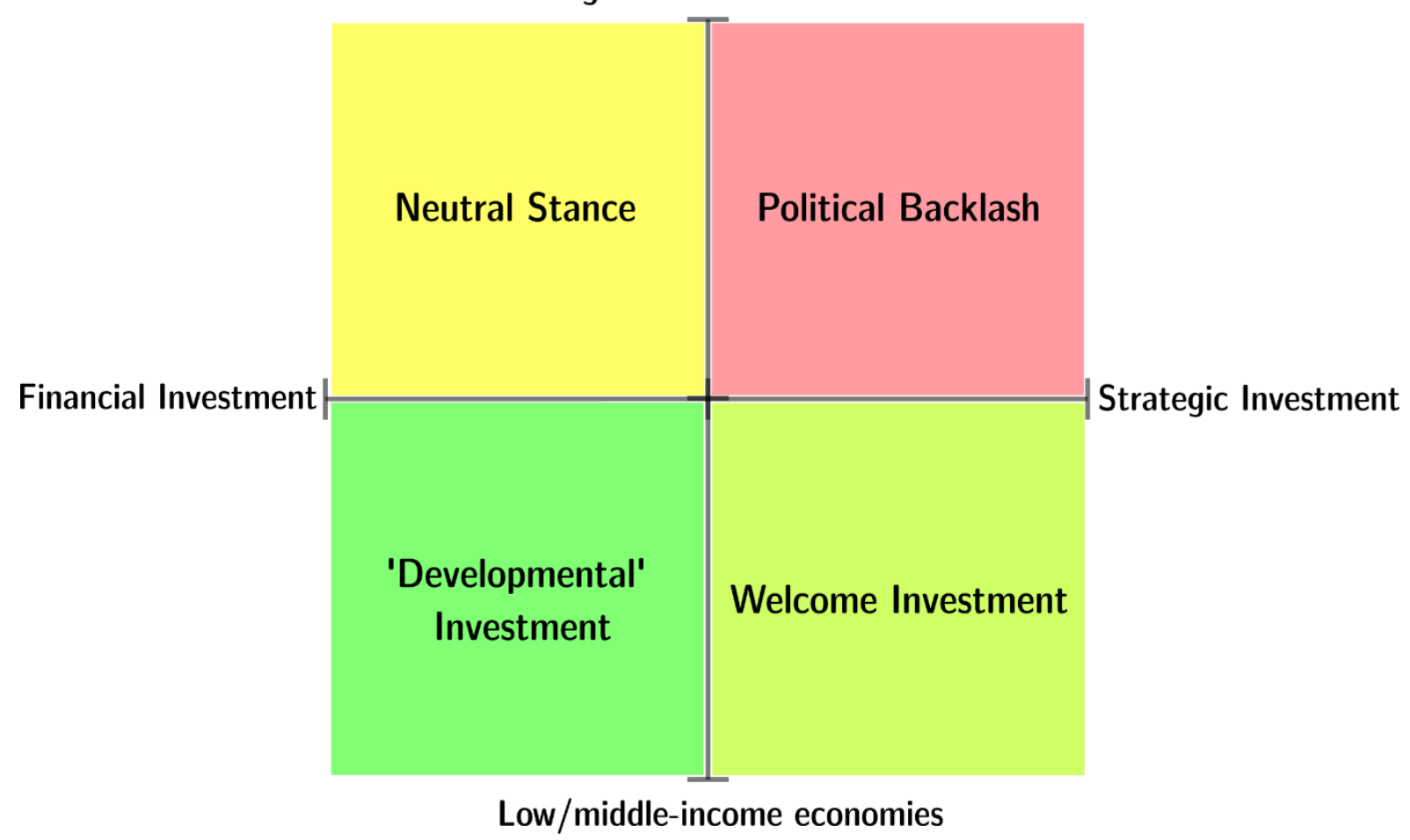

Figure 3: Host country reactions to foreign state investment

Three points are important to mention here. First, the distinctions between the different investment types and economies are not categorical, but they each represent a continuum. This means that hybrid forms are possible in both cases, for example when initial financial investment in a corporation grows into majority control over time. This was, for instance, the strategy of China's state-owned China Three Gorges Corporation (CTG) when it attempted a (failed) takeover bid for Portugal's utility corporation EDP after already owning 23 percent of the firm beforehand (Wise, 2019). In our typology, the CTG engagement would have then moved to the right if the bid had been successful.

Second, and following from the first point, our typology is not a predictive model, but a descriptive heuristic. We do not claim that political resistance will emerge once strategic investment flows into a high-income economy. However, and as we illustrate in our empirical examples below, the likelihood of political resistance is much higher in this constellation than in the case of a financial investment into a low/middle-income economy. In this sense, our typology is an analytical tool, which can help to navigate the polymorphic nature of foreign state investment beyond the focus on singular cases and investment types. 
Third, we emphasize that income levels can be vastly different within states. ${ }^{7}$ Regions like East Germany or the Italian South have significantly lower per capita incomes than their (high) national averages suggest. This could have variegated effects on the desirability of foreign (state-led) investment within host states. Similarly, the push for either investment attraction or blocking could stem from subnational actors that are interested in or against particular types of investment such as business interest organizations or trade unions in specific industries (see Bauerle Danzman, 2019). At the same time, we hold that the rules for attracting or blocking foreign state investment apply at the national scale (such as foreign investment screening). In addition, while we acknowledge that the power over the decision to discourage or attract state investment lies not only with the national government, we also hold that our heuristic reflects the tendency of high-income economies to choose different policy answers to state-led investment than lower-income economies.

\section{Hypotheses derived from our typology}

To strengthen the usefulness of our typology as a research tool, we derive four hypotheses from the previous discussion. This set of hypotheses can serve as the next step for future research and also informs our empirical illustration in the following section.

$\mathrm{H}_{1}$ : The more financial foreign state-led investment into high-income economies is, the more likely it will, ceteris paribus, be evaluated as politically neutral by the host government.

$\mathrm{H}_{2}$ : The more strategic foreign state-led investment into high-income economies is, the more likely it will, ceteris paribus, lead to a political backlash of the host government.

$\mathrm{H}_{3}$ : The more financial foreign state-led investment into middle-or low-income economies is, the more likely it will, ceteris paribus, be desired as development finance by the host government.

\footnotetext{
${ }^{7}$ We thank an anonymous reviewer for pointing this out to us.
} 
$\mathrm{H}_{4}$ : The more strategic foreign state-led investment into middle-or low-income economies is, the more likely it will, ceteris paribus, 'only' be welcomed by the host government.

By 'foreign state-led investment' we refer here to singular cases of investment. This means the hypotheses do not concern overall investment levels into a host country, which could also play a role (as a ceteris paribus condition). The hypotheses should hence be read as statements on how strong singular investment ties are either financial or strategic on the horizontal axis of Figure 3. The more an investment tends to one or the other side, the (less) likely is a specific reaction from the respective government. The following section specifies our framework empirically.

\section{Empirical Illustrations}

To illustrate our typology, we chose an empirical vignette for each of the quadrants from Figure 3 and each hypothesis from the previous section. These illustrations can serve as groundwork for a systematic analysis, both qualitative and quantitative, guided by our typology.

\section{Neutral Stance}

A classic example of the neutral stance of host states we identify in our typology is the longstanding engagement of Middle Eastern SWFs in German industrial firms. Once described as 'white knights from the Gulf' (Haberly, 2014), these investors have been beneficial in different phases of German postwar development. In a first phase starting in the 1970s, investment from Gulf SWFs became an attractive source of funding for large industrial firms. The first landmark investment was by the Kuwait Investment Authority (KIA), which bought a $14 \%$ share in carmaker Daimler in 1974 and remained a long-term shareholder ever since. This trend continued in the following decades, with large-scale investments into chemical giant Hoechst in 1982 (Tagliabue, 1982) or into Volkswagen in 1983. In a second phase before the GFC, German debates about the benefits and risks of foreign state-led investment led to a short period of skepticism and protectionist tendencies towards vehicles like SWFs around 2007 (Heep, 2008). However, as Thatcher and Vlandas $(2016,653)$ argue, a coalition between politicians and business associations soon advocated for more openness towards SWF investment after the GFC, and even actively tried to attract such investment to Germany (ibid., 
657). In 2009, a third phase was initiated by the Qatar Investment Authority (QIA) that acquired stakes in Volkswagen and construction firm Hochtief, thereby stabilizing these companies by filling the gaps left by former long-term shareholders (Haberly 2014, 306). This initiated an acceleration of Gulf money inflows with many landmark investments following in the immediate post-GFC years (Haberly, 2014). Until today, the topic of state-sponsored funds from the Gulf does not cause any political reverberations in the German political landscape. On the contrary, former chancellor Merkel, leading a grand coalition between social democrats and conservatives at the time, even called Qatari investment 'very welcome' as the Emirate prepares to invest EUR 10bn in the next decade into Germany (FAZ, 2018).

In our typology, the described investment ties would not be identical to 'pure' portfolio investment like that from the Norwegian SWF. Rather, the stakes of the Qatari or Kuwaiti funds in German firms are often blockholdings, and they are partly also strategic: the acquisition of a 9\% stake in Hochtief by the Qatari SWF was announced as a 'key deal to developing infrastructure for the 2022 football World Cup' (EIU, 2011). However, such equity holding to facilitate collaboration on infrastructure projects is different from outright technology transfer or asset capture by geoeconomic competitors. In this sense, real political backlash against such 'win-win' investment is rather unlikely.

\section{Political Backlash}

Such political backlash is the case where clearly strategic investment meets either strategic or security concerns on the side of the hosts. The example of the UK and Chinese state investment illustrates this case convincingly. The conservative Cameron government that took office in 2010 aimed to attract Chinese FDI in an attempt to shape a 'golden decade' between both countries (Parker, 2015). As an open and FDI-dependent economy, the UK pushed forward to create strong trade and investment ties with a rising global superpower. This initial euphoria gave way to rising skepticism and scrutiny of Chinese investment when state-owned China General Nuclear Power Group (CGN) was supposed to acquire a 33 percent stake of a nuclear project in the UK in 2016 (Ruddick, 2016). Citing security concerns, the UK government delayed its approval of the project, causing a major national discussion on the role of strategic Chinese state investment. The open and investment-attracting UK economy was now in a position where the combination of state investment into a sector of utmost importance for national (energy) security led to unexpected protectionist reflexes. The Brexit 
vote in June 2016 certainly contributed to more protectionist tendencies in the British political landscape, e.g. by giving more conservative forces in the Tory party additional impetus. ${ }^{8}$ Around the same time, the UK watchdog for Huawei, which was involved in the British telecom network, started to raise concerns about the participation of a supposedly Chinese statecontrolled firm in critical UK infrastructure (HCSEC, 2018). The political and media discussion now entirely moved away from the opportunities Chinese FDI promised and towards the associated security risks from state-controlled investment. The culmination of this rising protectionism took place in late 2020, when the Johnson government introduced a comprehensive investment screening mechanism as well as a bill seeking to prevent risks in critical infrastructure, like the now banned Huawei in the $5 \mathrm{G}$ network, to parliament. Both have crucially been driven by the rise of Chinese strategic investment and its political reverberations in the UK.

In our typology, this would be a typical case of (attempted) asset capture in a highincome economy, which results in political resistance. More specifically, the assets in question are in critical energy and telecom infrastructures, which increases the political sensitivity of the matter. The strong reaction, and even transformation of the inwards investment regime of the UK, is thereby not an international outlier if we consider the recent policy tightening in the EU and US vis-à-vis state-backed investment. This indicates a clear pattern for high-income economies, which decisively and in a rapid manner erect legal and political barriers against unwanted state investment.

\section{Welcome Investment}

In this category, the host state reactions to strategic investment are quite different, namely welcoming. In theory, middle- or low-income economies can profit more from (state) investment than high-income economies. ${ }^{9}$ In practice, foreign state investment is rarely

\footnotetext{
${ }^{8}$ The real effects Brexit had on the tightening of UK investment openness vis-à-vis China are disputed. On the one hand, Brexit certainly propelled more neoliberal social forces advocating for a 'Singapore-on-Thames' model of economic openness and liberalization (Paterson 2017). On the other hand, rising exceptionalist and nationalist tendencies due to Brexit also contributed to increased protectionism (Dent 2020). As Babic and Dixon (2022) show, there are however similar protectionist tendencies in cases like the UK and Germany (which did not leave the EU) when it comes to specifically Chinese investment, which is of interest here. Due to space constraints, we thus refer to future research to disentangle the effect of Brexit on this specific case (i.e. Chinese state-led investment). We thank an anonymous reviewer for pointing this issue out to us.

${ }^{9}$ Whether the welfare effects associated with (state) FDI factually materialize depends on a range of factors. Investment could for example be subject to elite rent seeking, or simply not lead to any welfare effects, e.g. by crowding out other investments (see Agosin \& Machado, 2005).
} 
disputed for reasons such as asset capture or know-how transfer in middle- or low-income economies. An interesting case in this respect is the acquisition of India's Essar Oil by Russian state-owned Rosneft in 2017. The USD 13bn deal established Russia as a major player in one of the largest energy markets in Asia. The deal itself was, however, quite controversial. Before its completion, the former Indian owners were reported to have already canceled the talks once and almost sold the firm to Rosneft competitor Saudi Aramco (Zhdannikov et al., 2016). Furthermore, after the settlement between Essar and Rosneft, Indian security agencies raised red flags about the transaction due to the inclusion of a strategically important port, which would fall under the control of a Russian SOE (The Asian Age, 2017). According to news sources, Indian prime minister Modi played a crucial role to get the deal over the line, also because the Rosneft offer was too valuable in terms of incoming investment (Zhdannikov et al., 2016). The deal was signed at the 2016 BRICS summit in Goa by Putin and Modi. Despite the cited problems and concerns related to the state-owned nature of Rosneft, it became clear that the largest FDI transaction into India was a welcome deal for the Indian government.

The described dynamics are a good example for welcome strategic investment. The acquisition was realized despite the mentioned odds, and with the intervention and support from the Indian government. It is clear that Rosneft's strategy can have geopolitical reverberations, especially given the proximity of the acquired port to Pakistan. At the same time, the Modi government seemed to clearly prioritize the financial benefits the deal would bring to one of its largest and most valuable energy firms. In many cases, geopolitical and security considerations will not be as prominent as they have been here, which makes the welcoming aspect even stronger. As an example, many governments of middle- and lowincome economies along the Chinese Belt and Road project show increasing interest for Chinese state-led infrastructure investment, such as countries in Central and Eastern Europe.

\section{‘Developmental' Investment}

Our last illustration concerns the intersection of financial investment and low- and middle-income economies. We contend that this form of foreign state investment is from the outside the least problematic, as most often the political and commercial interests of both actors will be complementary. This means that an objective to gain a return on investment from the sender-side meets the interest of receiving developmental capital inflows with few 'strings attached' on the side of the host state. A good example for such dynamics is the 
expansion of Chinese state-provided credit into Latin America. Led by the state-owned CDB and the China Export-Import Bank, those lenders have until today channeled over USD 130bn into the region (Gallagher \& Myers, 2021). As state-owned and state-backed institutions, these Chinese creditors have no market-driven pressure to demand quarterly returns on their investment, but can also 'sit out' negative phases. This makes them in many ways 'patient' capital providers (Kaplan, 2016). At the same time, such investment is not only welcome in many parts of the world, but often outright necessary for developmental reasons. For example, struggling regimes like Venezuela under Maduro are dependent on massive Chinese capital inflows. As Kaplan argues also for other Latin American cases, the host states seem to gain more political maneuverability through Chinese state-owned patient capital (Kaplan, 2016, 650). This is especially the case compared with institutional creditors like the IMF, who often attach structural reform demands to loans, and other short-term oriented 'Western' creditors.

Developmental financial investments such as credits, bond holdings, and others are hence often a desired investment form for governments of low- and middle-income economies. Different from the category of welcome investment, developmental investment often comes with active investment attraction efforts on the side of the receiving country. Host countries actively seek to attract this type of investment for different reasons such as development or rent capture. We should at the same time also be careful to observe the longterm implications of cross-border state-led credit expansion. Such investment forms can in the long run lead to dependencies and structural power positions of states as lenders, especially where debtors run into structural economic difficulties. While there has been justified criticism towards the image of a Chinese 'debt trap diplomacy', recent research has shown that Chinese state lending entails controversial provisions such as 'unusual confidentiality clauses' or the possibility of domestic political influence by the lender (Gelpern et al., 2021). Such insights provide a necessary adjustment of the idea that state-owned credit expansion is characterized sufficiently as 'normal' patient capital. We hence put this category of 'developmental' investment in quotation marks, as structural factors of dependency and unequal exchange relations certainly play an important role here.

\section{Conclusion}

What is state capital in a globalized world? The rise of new, cross-border forms of state investment has sparked a renewed interest in the role of states as providers of foreign capital. 
Among the $\mathrm{CC}$ and broader political economy literature, the main focus was on describing the 'patient' aspects of cross-border state lending and investment, which constitutes an important part of the phenomenon. At the same time, we argued, it is the polymorphic and variegated nature of transnational state capital that should push scholarly inquiry beyond the boundaries of specific time frames, specific investment vehicles, or specific target states. If we want to make sense of the rise of state capital in the global economy, and its domestic effects, we need to broaden our analytical lenses and better equip our conceptual toolboxes. This paper aimed at doing so, by introducing a typology based on two main dimensions: the forms and strategies of cross-border state investors, and the types of hosts of such investment. Our typology not only captures each dimension on its own, but shows how we can think both together in order to assess the domestic effects of state investment in a globalized world. Our typology is thereby an analytical heuristic and not a categorical exercise: neither states as investors, nor states as hosts will fit neatly into a specifically designed category. Rather, we conceptualize each dimension as a continuum. Investors and hosts can and will move on this continuum over time and in the course of societal negotiation processes. Our typology can help to make sense and to trace these changes as both states as investors as well as the investment hosts change their preferences and standpoints.

The work conducted in this paper is then first and foremost an empirically illustrated proposal of how to move forward in better understanding the variegated nature of crossborder state investment. This is an important task in the age of the 'new' state capitalism and the recent intensifications of international competition and conflict, also with regards to a 'statist' China. By providing a typology that is in principle applicable to states as owners and hosts worldwide, we emphasize the globalized nature of foreign state investment. We advocate for a perspective that integrates different functions like patient capital into this typology, but does not reduce state capital to such a form. With this, our work connects to previously articulated critiques of the CC-paradigm in political economy that, in its stylized form, does not capture the plurality of dynamics governing capitalist variety (Peck \& Theodore, 2007, 750). One key dynamic is the role of foreign state-led investment, which is in our view not adequately captured as patient capital serving a role for CMEs and MMEs. In fact, our empirical vignettes extending this focus to cases like the UK (a LME), India or even Latin America as a whole suggest that an ideal-typical understanding of capitalist varieties needs to be dynamized and rethought in order to capture real-world developments such as the rise of 
foreign state capital in a globalized world and its political reverberation in and across different 'capitalisms'.

We hope to constructively push forward discussions on the emergence of states as large-scale investors in particular, and on the new state capitalism in general. We see two main avenues for how the debate could continue. The first is to challenge, extend, and specify the conceptual work conducted in this paper. While we cover the main characteristics of transnational state capital, we did not touch upon specific forms which might play a stronger role in future constellations (for example, the role of states as veto players through so-called 'golden shares'). We thus strongly encourage further critique and refinement of the presented typology. Second, we hope to see much more empirical work on the issue, from both qualitative and quantitative angles. Notwithstanding existing impressive research on state capitalism and foreign state investment we referenced in this paper, we are hopefully only at the beginning of a research program that breaks new ground in better understanding why, how, and with which consequences states rise as global owners and investors. We believe that our typology and the derived hypotheses are an important building block in this endeavor, and can contribute to realize empirically driven insights into a key transformative moment of global capitalism for the next decades.

\section{References}

Abdelal, R. (2013). The profits of power: Commerce and realpolitik in Eurasia. Review of International Political Economy, 20(3), 421-456.

Agosin, M. R., \& Machado, R. (2005). Foreign Investment in Developing Countries: Does it Crowd in Domestic Investment? Oxford Development Studies, 33(2), 149-162.

Albert, M. (1993). Capitalism against capitalism. Wiley.

Amable, B. (2003). The diversity of modern capitalism. Oxford University Press.

Arslanalp, S., \& Tsuda, T. (2014). Tracking Global Demand for Emerging Market Sovereign Debt. IMF Working Papers 14/39. 
Bauerle Danzman, S. (2019). Merging Interests: When Domestic Firms Shape FDI Policy. Cambridge: Cambridge University Press.

Berlich, C., Daut, F., Freund, A. C., Kampmann, A., Killing, B., Sommer, F., \& Wöhrmann, A. (2017). Deutsche Bahn AG: A former monopoly off track? The CASE Journal, 13(1), 25-58.

Bolton, P., Samama, F., \& J. Stiglitz, J. (eds.) (2011). Sovereign wealth funds and long-term investing. New York: Columbia University Press.

Braun, B., \& Deeg, R. (2020). Strong Firms, Weak Banks: The Financial Consequences of Germany's Export-Led Growth Model. German Politics, 29(3), 358-381.

Braunstein, J. (2018). Domestic Sources of Twenty-first-century Geopolitics: Domestic Politics and Sovereign Wealth Funds in GCC Economies. New Political Economy, 24(2), 197-217.

Browning, S., \& Bennett, O. (2021). National Security and Investment Bill 2019-21 (No. CBP8784; Briefing Paper). House of Commons. https://researchbriefings.files.parliament.uk/documents/CBP-8784/CBP-8784.pdf

Callaghan, H. (2015). Something left to lose? Network preservation as a motive for protectionist responses to foreign takeovers. Review of International Political Economy, 22(2), 391-418.

Carney, R. W. (2018). Authoritarian Capitalism. Sovereign Wealth Funds and State-Owned Enterprises in East Asia and Beyond. Cambridge University Press.

Crooks, E. (2008, July 27). Alarm raised on EDF bid for British Energy. Financial Times. https://www.ft.com/content/89dd7c04-5c0a-11dd-9e99-000077b07658

Cuervo-Cazurra, A. (2018). Thanks but no thanks: State-owned multinationals from emerging markets and host-country policies. Journal of International Business Policy, 1(3-4), 128-156.

Culpepper, P. D. (2005). Institutional Change in Contemporary Capitalism: Coordinated Financial Systems since 1990. World Politics, 57(2), 173-199.

De Jong, B., \& Zwartkruis, W. (2020). The EU Regulation on Screening of Foreign Direct Investment: A Game Changer? European Business Law Review, 31(3), 447-474.

Deconinck, K. (2019). New evidence on concentration in seed markets. Global Food Security, 23, 135- 
138.

Deeg, R., \& Hardie, I. (2016). 'What is patient capital and who supplies it?' Socio-Economic Review, 14(4), 627-645.

Deeg, R., Hardie, I. \& Maxfield, S. (2016). What Is Patient Capital, and Where Does It Exist? SocioEconomic Review 14(4): 615-25.

Dent, C. M. (2020). Brexit, Trump and Trade: Back to a Late 19th Century Future? Competition \& Change 24(3-4), 338-57.

EDF. (2016). EDF signs an agreement for the acquisition of Global Resource Options, Inc, pursuing its expansion in renewables in the United States. Électricité de France. https://www.edf.fr/sites/default/files/contrib/groupe-edf/espaces-dedies/espacemedias/cp/2016/cp_edf_20160425_grosolar_va.pdf

EIU. (2011, January 10). Qatar buys 9\% stake in Hochtief. The Economist.

http://country.eiu.com/article. aspx?articleid=1297730514\&Country=Qatar\&topic=Economy\& subtopic=Recent+developments\&subsubtopic=Economic+performance:+Qatar+buys+9\%25+s take+in+Hochtief+

England, A., \& Massoudi, A. (2020, May 25). 'Never waste a crisis': Inside Saudi Arabia's shopping spree. https://www.ft.com/content/af2deefd-2234-4e54-a08a-8dbb205f5378

FAZ. (2018, September 7). Katar will in Deutschland zehn Milliarden Euro investieren. Frankfurter Allgemeine Zeitung. https://www.faz.net/aktuell/wirtschaft/katar-will-in-deutschland-zehnmilliarden-euro-investieren-15776230.html

Gallagher, K. P., \& Myers, M. (2021). China-Latin America Finance Database. Inter-American Dialogue. https://www.thedialogue.org/map_list/

Gelpern, A., Horn, S., Morris, S., Parks, B., \& Trebesch, C. (2021). How China Lends: A Rare Look into 100 Debt Contracts with Foreign Governments. https://doi.org/10.2139/ssrn.3840991

Gilson, R. J. (2001). The Globalization of Corporate Governance: Convergence of Form or Function. American Journal of Comparative Law, 49(2), 329-357. 
Haberly, D. (2014). White Knights from the Gulf: Sovereign Wealth Fund Investment and the Evolution of German Industrial Finance: White Knights from the Gulf. Economic Geography, 90(3), 293320.

Haberly, D., \& Wójcik, D. (2017). Earth Incorporated: Centralization and Variegation in the Global Company Network. Economic Geography, 93(3), 241-266.

Hall, P. A., \& Soskice, D. (2001). An Introduction to Varieties of Capitalism. In P. A. Hall \& D. Soskice (Eds.), Varieties of Capitalism (pp. 1-68). Oxford University Press.

Hannas, W. C., \& Tatlow, D. K. (Eds.). (2020). China's quest for foreign technology: Beyond espionage. Routledge.

Hassel, A. (2014). Adjustments in the Eurozone: Varieties of Capitalism and the Crisis in Southern Europe. LEQS Paper 76.

Heredia, L. et al. (2021). Global Asset Management 2021. Boston Consulting Group. https://webassets.bcg.com/79/bf/d1d361854084a9624a0cbce3bf07/bcg-global-asset-management2021-jul-2021.pdf.

HCSEC. (2018). Huawei Cyber Security Evaluation Centre Oversight Board Annual Report. Huawei Cyber Security Evaluation Centre.

https://assets.publishing.service.gov.uk/government/uploads/system/uploads/attachment_d ata/file/727415/20180717_HCSEC_Oversight_Board_Report_2018_-_FINAL.pdf

Heep, S. (2008). Staatsfonds ante portas: Deutsche Reaktionen auf den wachsenden Einfluss staatlicher Investitionsgesellschaften. China Analysis, 65.

Helleiner, E., \& Lundblad, T. (2008). States, Markets, and Sovereign Wealth Funds. German Policy Studies, 4(3), 59-82.

Henderson, G. E. (2013). The Regulation of Foreign Direct Investment by State-Owned Enterprises in Canada. SSRN Electronic Journal. https://doi.org/10.2139/ssrn.2281395

Jungbluth, C. (2018). Kauft China systematisch Schlüsseltechnologien auf? Chinesische Firmenbeteiligungen in Deutschland im Kontext von "Made in China 2025" (Global Economic 
Dynamics). Bertelsmann Stiftung.

Kaplan, S. B. (2016). Banking unconditionally: The political economy of Chinese finance in Latin America. Review of International Political Economy, 23(4), 643-676.

Kwiatowski, G., \& Augustynowicz, P. (2015). State-owned Enterprises in the Global Economy Analysis based on Fortune Global 500 List. Proceedings of the MakeLearn and TIIM Joint International Conference, 1739-1747.

Lane, C. (2003). Changes in Corporate Governance of German Corporations: Convergence to the Anglo-American Model? Competition \& Change, 7(2-3), 79-100.

Lee, C. K. (2017). The specter of global China: Politics, labor, and foreign investment in Africa. The University of Chicago Press.

Lenihan, A. T. (2014). Sovereign Wealth Funds and the Acquisition of Power. New Political Economy, 19(2), 227-257.

Marois, T. (2021). A Dynamic Theory of Public Banks (and Why it Matters). Review of Political Economy, 1-16.

Mazzucato, M. (2015). Innovation, the State and Patient Capital. The Political Quarterly, 86, 98-118. Mills, M., Blossfeld, H.-P., Buchholz, S., Hofäcker, D., Bernardi, F., \& Hofmeister, H. (2008). Converging Divergences?: An International Comparison of the Impact of Globalization on Industrial Relations and Employment Careers. International Sociology, 23(4), 561-595.

Monk, A. (2009). Recasting the Sovereign Wealth Fund Debate: Trust, Legitimacy, and Governance. New Political Economy, 14(4), 451-468.

NBIM. (2021, June 25). Norges Bank Investment Management. The Fund. https://www.nbim.no/ Newnham, R. (2011). Oil, Carrots, and Sticks: Russia's Energy Resources as a Foreign Policy Tool. Journal of Eurasian Studies, 2(2), 134-143.

Norrestad, F. (2021a). Assets under management (AUM) of sovereign wealth funds (SWFs) worldwide from 2008 to 2021. Statista. https://www.statista.com/statistics/1267499/assets-undermanagement-of-swfs-worldwide/ 
- (2021b). Value of assets managed by hedge funds worldwide from 1997 to 2020. Statista.

https://www.statista.com/statistics/271771/assets-of-the-hedge-funds-worldwide/

OECD (2020). Equity Injections and Unforeseen State Ownership of Enterprises during the COVID-19

Crisis. OECD Policy Responses to Coronavirus (COVID-19). https://www.oecd-

ilibrary.org/finance-and-investment/equity-injections-and-unforeseen-state-ownership-of-

enterprises-during-the-covid-19-crisis_3bdb26f0-en.

Parker, G. (2015, November 20). Osborne hails 'golden decade' in Sino-British relations. Financial

Times. https://www.ft.com/content/6d107dc4-5fae-11e5-a28b-50226830d644

Paterson, O. (2017, November 21). Don't Listen to the Terrified Europeans. The Singapore Model Is Our Brexit Opportunity. The Telegraph. https://www.telegraph.co.uk/news/2017/11/20/dontlisten-terrified-europeans-singapore-model-brexit-opportunity/.

Peck, J., \& Theodore, N. (2007). Variegated Capitalism. Progress in Human Geography 31(6): 731-72.

Rose, P. (2008). Sovereigns as Shareholders. North Carolina Law Review, 87(1), 102-166.

Ruddick, G. (2016). Why have ministers delayed final approval for Hinkley Point C? The Guardian. https://www.theguardian.com/uk-news/2016/jul/29/hinkley-point-c-why-has-governmentdelayed-final-approval

Stompfe, P. (2020). Foreign Investment Screening in Germany and France. In S. Hindelang \& A. Moberg (Eds.), YSEC Yearbook of Socio-Economic Constitutions. Springer International Publishing.

Thatcher, M., \& Vlandas, T. (2016). Overseas state outsiders as new sources of patient capital: Government policies to welcome Sovereign Wealth Fund investment in France and Germany. Socio-Economic Review, 14(4), 647-668.

The Asian Age. (2017). IB, Home Ministry red flag Essar-Rosneft deal. The Asian Age. https://www.asianage.com/business/companies/240617/ib-home-ministry-red-flag-essarrosneft-deal.html

UNCTAD (2020). World Investment Report: International Production beyond the Pandemic. Geneva; 
New York: United Nations. https://unctad.org/system/files/official-

document/wir2020_en.pdf.

Viallet-Thévenin, S. (2015). From national champion to international champion. Revue Française de Science Politique, 65(5), 761-783.

Wise, P. (2019, April 24). China Three Gorges' €9bn bid for Portuguese utility EDP collapses. Financial Times. https://www.ft.com/content/c4e7a0ae-66b7-11e9-9adc-98bf1d35a056

Zhdannikov, D., Verma, N., \& Golubkova, K. (2016, November 16). Exclusive: Oil wars-How Kremlin's \$13 billion Indian deal almost fell apart. Reuters. https://www.reuters.com/article/us-russiaindia-saudi-oil-idUSKBN13B083

Zimmerman, E. J. (2019). The Foreign Risk Review Modernization Act: How CFIUS became a Tech Office. 34, 1267-1304. 